\title{
STRUKTUR UKURAN DAN FAKTOR KONDISI IKAN TERBANG, Cheilopogon cyanopterus DAN C. spilopterus DI PERAIRAN INDONESIA TIMUR
}

\author{
Augy Syahallatua", Asikin Djamali"), Petrus Makatipu"), dan Rusli Rentua*)
}

\begin{abstract}
ABSTRAK
Kajian struktur panjang dan faktor kondisi dilakukan untuk 2 jenis ikan terbang, Cheilopogon cyanopterus dan C. spilopterus yang dikumpulkan antara bulan Mei sampai dengan Oktober 2005 dari 3 lokasi di perairan Indonesia timur, yaitu Selat Makassar, Laut Sulawesi, dan Laut Arafura. Contoh jkan terbang diperoleh dari hasil tangkapan nelayan dengan jaring insang, diidentifikasi, diukur panjang total, dan ditimbang bobot. Jumlah contoh yang memadai untuk jenis cyanopterus ditemukan di 3 lokasi, namun untuk contoh spilopterus hanya di 2 lokasi (Laut Sulawesi dan Laut Arafura). Struktur ukuran ke-2 jenis ikan terbang ini menunjukkan bahwa keseluruhan contoh adalah ikan-ikan yang telah dewasa dan pernah memijah, walaupun panjang total jenis cyanopterus dari Selat Makassar cenderung lebih kecil dari 2 lokasi lain. Kondisi ke-2 jenis ikan ini dari 3 lokasi tidak menunjukkan perbedaan yang nyata (selama periode penelitian). Hal ini, mengindikasikan bahwa musim pemijahan yang mempengaruhi karakter fisiologis pada ke-2 jenis ikan ini berlangsung dalam kurun waktu yang relatif sama di perairan Indonesia timur.
\end{abstract}

KATA KUNCI: ikan terbang, struktur ukuran, faktor kondisi, Indonesia timur

ABSTRACT: Size structure and condition factor of flyingfishes, Cheilopogon cyanopterus, and C. spiloptenus in Eastern Indonesla waters. By: Augy Syahailatua, As/kin Djamall, Petrus Makatipu, and Rusll Rentua

Study on size structure and condition factor $(\mathrm{kn})$ of two flyingfishes species, Cheilopogon cyanopterus, and C. spilopterus was conducted from May to October 2005. Samples were collected using a gill net in three main fishing areas in eastem Indonesia waters, such as Makassar Strait, Sulawesi Sea, and Arafura Sea. Size structure of these two species shows that all fishes caught are adults, and spawn previously. However, total length of cyanopterus from Makassar Strait tended to be smaller than from other two sampling sites. The condition of these two species from three sites was also shown no significant difference during the study. It indicates that spawning of these two species may occur at the same period, therefore these physiological chararcters seem to be identical in the eastem Indonesia waters.

KEYWORDS: flyingfishes, size structure, condition factor, Eastern Indonesia

\section{PENDAHULUAN}

Aktivitas penangkapan ikan terbang di Indonesia lebih banyak dilakukan di perairan bagian timur, karena perairan didominasi oleh lautlaut yang dalam, seperti Laut Sulawesi dan Laut Banda. Kondisi laut-laut dalam yang bersifat oseanik merupakan habitat yang sangat cocok bagi ikan terbang (Hutomo ot al., 1985). Sampai saat ini, lokasi penangkapan ikan terbang yang sangat dikenal adalah perairan Selat Makassar dan Laut Flores. Hal ini, terbukti dengan sejak tahun 1970-an, Propinsi Sulawesi Selatan sudah menjadikan telur ikan terbang sebagai salah satu komoditi ekspor.

Tingkat eksploitasi telur ikan terbang dirasakan cukup tinggi, dan jika tidak dikendalikan secara baik, dapat berdampak pada penurunan stok perikanan, dan pada akhirnya akan mengakibatkan kondisi tangkap lebih. Selain Sulawesi Selatan, aktivitas penangkapan ikan terbang juga dilakukan di beberapa daerah lain seperti di Sulawesi utara, terutama di Kepulauan Talaud dan di Propinsi Maluku (Ambon, Saparua, dan Kei Besar). Namun, di Sulawesi Utara dan Maluku, perikanan ikan terbang hanya dikelolah secara tradisional. Pada umumnya, nelayan lokal melaut untuk 5 sampai dengan 6 jam dalam 1 hari, dan hanya mengutamakan hasil tangkapan ikan terbang. Dengan demikian, Propinsi Sulawesi Selatan merupakan daerah utama penghasil telur ikan terbang di Indonesia (Nessa et al., 1977; Dwiponggo et al., 1983; Hutomo et al., 1985).

Ikan terbang termasuk dalam kelompok ikan pelagis kecil (small pelagic species) dengan bentuk tubuh yang kompres berdiameter antara 2

\footnotetext{
7. Penelit pada Pusat Penelitian Oseanografl-Lembaga IImu Pengetahuan Indonesia, Ancol-Jakarta

") Peneliti pada UPT Loka Konservasi Biota Laut- Lembaga Ilmu Pengetahuan Indonesia, Bitung
} 
sampai dengan $5 \mathrm{~cm}$, dan panjang baku dapat mencapai $38 \mathrm{~cm}$ (pada umumnya marga Cheilopogon sp., Parin, 1999). Jenis yang tercatat dari perairan Selat Makassar adalah Cypselurus altipennis, C. oxycephalus, C. nigricans, C. poecilopterus, C. spilopterus, C. Oligolepis, dan Evalontia micropterus (Nessa et al., 1977; Dwiponggo et al., 1983; Hutomo et al., 1985). Di perairan Tual (Maluku Tenggara) telah diidentifkasi 2 jenis ikan terbang yaitu, Cypselurus oligolepis dan C. spilopterus (Syam et al., 2004). Sedangkan di perairan Teluk Manado terdapat jenis Parexocoetus brahypterus, Cypelurus poecilopterus, C. cyanopterus, C. spilopnoterus, C. atrisignis, C. spilopterus, dar. C. suttoni (Bataragoa, 1998). Namun sejak tahun 1999, ke-5 jenis terakhir dari genera Cypselurus telah diklasifikasikan ke dalam genus Cheilopogon (Parin, 1999).

Ikan terbang jenis Cheilopogon cyanopterus dan C. spilopterus merupakan jenis yang sebaran geografis luas dan tertangkap dengan jumlah yang melimpah (Syahailatua, 2005; tidak dipublikasikan). Kimura \& Matsuura (2003) mengidentifikasi Cheilopogon cyanopterus (D 12 sampai dengan 15; A 9 sampai dengan 10; P1 12 sampai dengan 14; dan PDS 35 sampai dengan 40) dan C. spilopterus (D 12 sampai dengan 14; $A$ 10 sampai dengan 11 ; P1 14 sampai dengan 15; PDS 26 sampai dengan 29). Kedua jenis ini memiliki bentuk tubuh yang hampir sama, ke-2 rahang sama panjang; gigi pada ke-2 rahang jelas. Pada jenis Cheilopogon cyanopterus sirip punggung terdapat bintik hitam; sirip dada biru kehitaman tanpa bintik-bintik, panjang baku (SL) mencapai $34 \mathrm{~cm}$, sedangkan jenis C. spilopterus memiliki sirip punggung pada umumnya tidak terdapat bintik hitam; sirip dada keabuan dengan beberapa bintik hitam dengan SL mencapai $25 \mathrm{~cm}$.

Pengamatan struktur ukuran panjang dan faktor kondisi ikan terbang dilakukan untuk mendapatkan informasi tentang distribusi ukuran dan kondisi ikan yang berkaitan dengan pengaruh musim, atau perkembangan gonad. Dengan informasi biologi ini, diharapkan dapat diperlukan sebagai salah satu masukan dalam pengelolaan sumber daya perikanan ikan terbang di Indonesia.

\section{BAHAN DAN METODE}

Spesimen ikan diambil dari hasil tangkapan nelayan yang menggunakan jaring insang hanyut (drift gill nets) di perairan Selat Makassar, Laut Sulawesi dan Laut Arafura (Gambar 1). Pengumpulan contoh ikan dilakukan dari bulan Mei sampai dengan Oktober 2005 (Tabel 1). Setiap pengumpulan contoh, ikan hasil tangkapan diambil secara acak, supaya semua kelas ukuran dapat terwakili. Selanjutnya contoh ikan dibawa ke laboratorium, untuk diidentifikasi jenis mengikuti kunci identifikasi (Parin, 1999; Kimura \& Matsuura, 2003). Kemudian, untuk setiap contoh ikan dilakukan pengukuran panjang total (cm, ketelitian $1 \mathrm{~mm}$ ) dan penimbangan bobot $(\mathrm{g}$, ketelitian 0,1 $\mathrm{mg}$ ).

Distribusi ukuran panjang digambarkan dalam histogram dengan selang panjang 0,5 cm, sedangkan analisis faktor kondisi dikaji dengan menggunakan rumus regresi panjang bobot, yaitu $W=a L^{b}$ atau dapat ditransformasikan ke dalam bentuk logaritma, yaitu:

$$
\log W=\log a+b \log L
$$

di mana:

$$
\begin{aligned}
& W=\text { bobot individu dalam } \mathrm{g} \\
& L=\text { panjang total dalam } \mathrm{cm} \\
& a=\text { nilai intersep } \\
& b=\text { nilai kemiringan garis regresi }
\end{aligned}
$$

Berdasarkan pada persamaan ini, diperoleh nilai bobot dugaan individu ikan (W'), dan selanjutnya, niiai $W^{\prime}$ dibandingkan dengan nilai bobot ikan benar (W), sehingga dihasilkan faktor kondisi relatif $(\mathrm{Kn})$, yang secara sederhana dapat ditulis $\mathrm{Kn}=\mathrm{W} \mathbf{W}^{\prime}$ (Cone, 1989). Variasi $\mathrm{Kn}$ antar lokasi dan jenis dilakukan dengan ANOVA (Analysis of Variance), dan diuji dalam beberapa kombinasi sesuai dengan kelengkapan data yang tersedia.

\section{HASIL DAN BAHASAN}

\section{Sebaran Ukuran Panjang}

Struktur ukuran Cheilopogon cyanopterus dan C. spilopterus yang tertangkap dengan jaring insang, masing-masing terdapat pada selang panjang total 15,3 sampai dengan $34,3 \mathrm{~cm}$ dan 19,9 sampai dengan $32,9 \mathrm{~cm}$ dengan selang bobot total (basah) 4,8 sampai dengan $290,0 \mathrm{~g}$ dan 66,7 sampai dengan 289,9 g (Tabel 2, Gambar 2 dan 3). Sebaran panjang total ke-2 jenis ikan terbang ini tidak memperlihatkan pola yang berbeda nyata, namun panjang total rata-rata jenis spilopterus $(28,3 \pm 2,2 \mathrm{~cm})$ lebih dari cyanopterus $(22,1 \pm 1,8$ $\mathrm{cm})$. Di samping itu, khusus untuk jenis cyanopterus, ukuran panjang total rata-rata yang tertangkap di Selat Makassar $(18,8 \pm 0,9 \mathrm{~cm})$ lebih kecil dari 2 lokasi pengambilan contoh yang lain, yaitu Laut Sulawesi $(27,1 \pm 3,0 \mathrm{~cm})$ dan Laut 


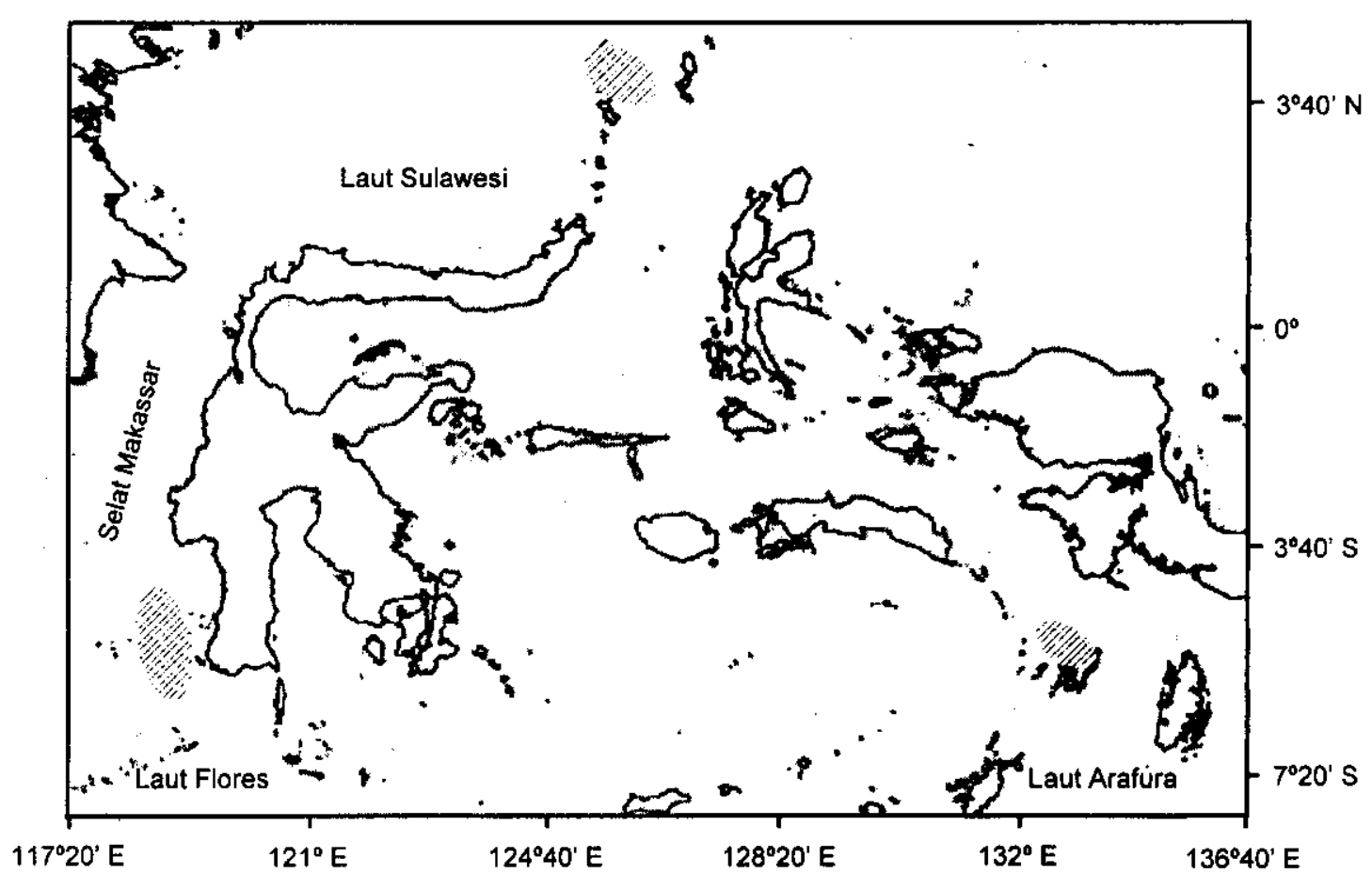

Gambar 1. Lokasi pengumpulan (bagian yang diarsir) contoh ikan terbang dari perairan Selat Makassar, Laut Sulawesi, dan Laut Arafura, selama bulan Mei sampai dengan Oktober 2005.

Figure 1. Sampling sites (shade in) of flyingfishes in Makassar Strait, Sulawesi Sea, and Arafura Sea, May to October 2005.

Tabel 1. Jumlah contoh ikan terbang C. cyanopterus dan C. spilopterus yang terkumpul dari 3 lokasi selama bulan Mei sampai dengan Oktober 2005

Table 1. Numbers of flyingfishes samples, C. cyanopterus and C. spilopterus collected from 3 sites, May to October 2005

\begin{tabular}{|c|c|c|c|c|c|c|c|}
\hline \multirow{2}{*}{ Jenis/Species } & \multirow{2}{*}{ Lokasi/Sites } & \multicolumn{6}{|c|}{ Bulan/Month } \\
\hline & & MeilMay & Juni/Juny & Juli/July & Ags/Augst & Sept/Sept & Okt/Oct \\
\hline \multirow{5}{*}{$\begin{array}{l}\text { C. } \\
\text { cyanopterus }\end{array}$} & Selat & & & & & & \\
\hline & $\begin{array}{l}\text { Makassar/ } \\
\text { Makassar } \\
\text { Strait }\end{array}$ & 50 & 95 & 50 & - & - & - \\
\hline & Laut & & & & & & \\
\hline & $\begin{array}{l}\text { Sulawesi/ } \\
\text { Sulawesi } \\
\text { Sea }\end{array}$ & 28 & 24 & 17 & 14 & 14 & 14 \\
\hline & $\begin{array}{l}\text { Laut Arafura/ } \\
\text { Arafura Sea }\end{array}$ & - & 12 & 40 & 16 & 14 & 9 \\
\hline \multirow[t]{5}{*}{ C. spilopterus } & Selat & & & & & & \\
\hline & $\begin{array}{l}\text { Makassar/ } \\
\text { Makassar } \\
\text { Strait }\end{array}$ & - & - & - & - & - & - \\
\hline & Laut & & & & & & \\
\hline & $\begin{array}{l}\text { Sulawesi/ } \\
\text { Sulawesi } \\
\text { Sea }\end{array}$ & 28 & 46 & 46 & 22 & 30 & 42 \\
\hline & $\begin{array}{l}\text { Laut Arafural } \\
\text { Arafura Sea }\end{array}$ & - & 30 & 14 & 28 & 21 & 30 \\
\hline
\end{tabular}


Tabel 2. Ringkasan panjang total dan bobot total dari C. cyanopterus dan spilopterus yang tertangkap dengan jaring insang di perairan Selat Makassar, Laut Sulawesi, dan Laut Arafura, bulan Mei sampai dengan Oktober 2005

Table 2. Summary of total length and weight of C. cyanopterus and C. spilopterus collected from Makassar Strait, Sulawesi, dan Arafura Seas, May to October 2005

\begin{tabular}{|c|c|c|c|c|c|c|c|}
\hline \multirow[b]{2}{*}{ Jenis/Species } & \multirow[b]{2}{*}{ ind./n } & \multicolumn{3}{|c|}{$\begin{array}{l}\text { Panjang total }(\mathrm{cm}) / \\
\text { Total length }(\mathrm{cm})\end{array}$} & \multicolumn{3}{|c|}{$\begin{array}{l}\text { Bobot total }(g) / \\
\text { Wet weight }(g)\end{array}$} \\
\hline & & Min. & Max. & $\begin{array}{c}\text { Rata }^{- \text {rata }}(\mathrm{SD}) / \\
\text { Mean (SD) }\end{array}$ & Min. & Max. & $\begin{array}{l}\text { Rata-rata } \\
\text { (SD) } / \\
\text { Mean (SD) }\end{array}$ \\
\hline \multicolumn{8}{|l|}{ C. cyanopterus } \\
\hline $\begin{array}{l}\text { Selat Makassar/ } \\
\text { Makassar Strait }\end{array}$ & 195 & 15,3 & 21,4 & $18,8(0,9)$ & 35,1 & 61,8 & $47,1(5,1)$ \\
\hline $\begin{array}{l}\text { Laut Sulawesi/ } \\
\text { Sulawesi Sea }\end{array}$ & 111 & 20,3 & 34,3 & $27,1(3,0)$ & 71,6 & 290,0 & $162,6(45,8)$ \\
\hline $\begin{array}{l}\text { Laut Arafural } \\
\text { Arafura Sea } \\
\text { C. spilopterus }\end{array}$ & 91 & 25,2 & 31,5 & $25,2(2,0)$ & 82,0 & 242,0 & $119,3(30,7)$ \\
\hline $\begin{array}{l}\text { Laut Sulawesi/ } \\
\text { Sulawesi Sea }\end{array}$ & 198 & 19,9 & 32,5 & $28,4(2,3)$ & 66,7 & 289,9 & $181,1(38,8)$ \\
\hline $\begin{array}{l}\text { Laut Arafural } \\
\text { Arafura Sea }\end{array}$ & 123 & 22,0 & 32,9 & $28,1(2,1)$ & 83,0 & 246,0 & $157,0(30,5)$ \\
\hline
\end{tabular}

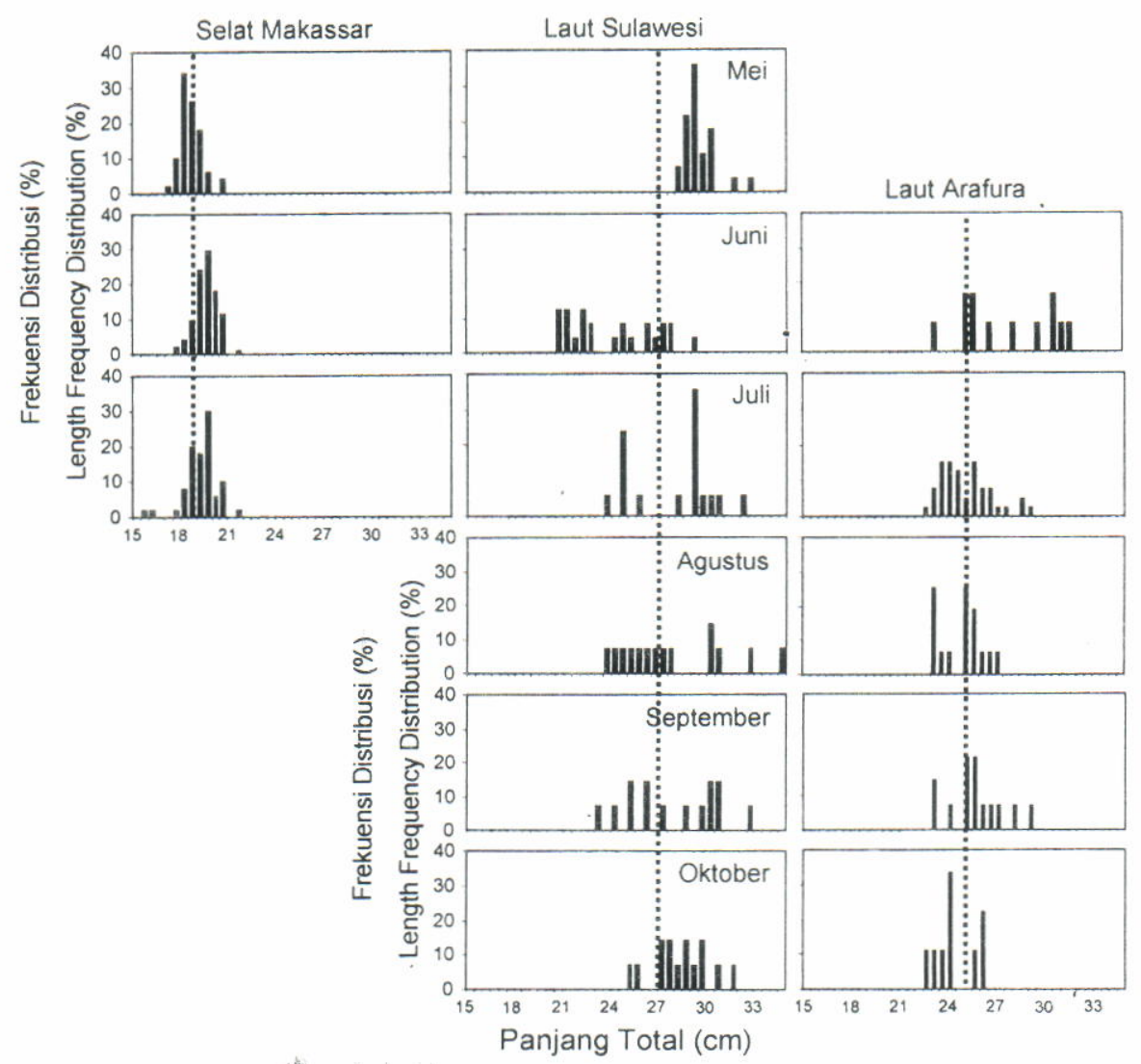

Gambar 2. Distribusi frekuensi panjang total $(\mathrm{cm})$ ikan terbang, C. cyanopterus yang tertangkap dengan jaring insang di perairan Indonesia Timur.

Keterangan: Garis putus-putus adalah panjang, rata-rata contoh

Figure 2. Length frequency distribution $(\mathrm{cm})$ flyingfishes, C. cyanopterus caught by gill net in Eastern Indonesia waters.

Remarks: Discontinued lines indicate the average length of samples 


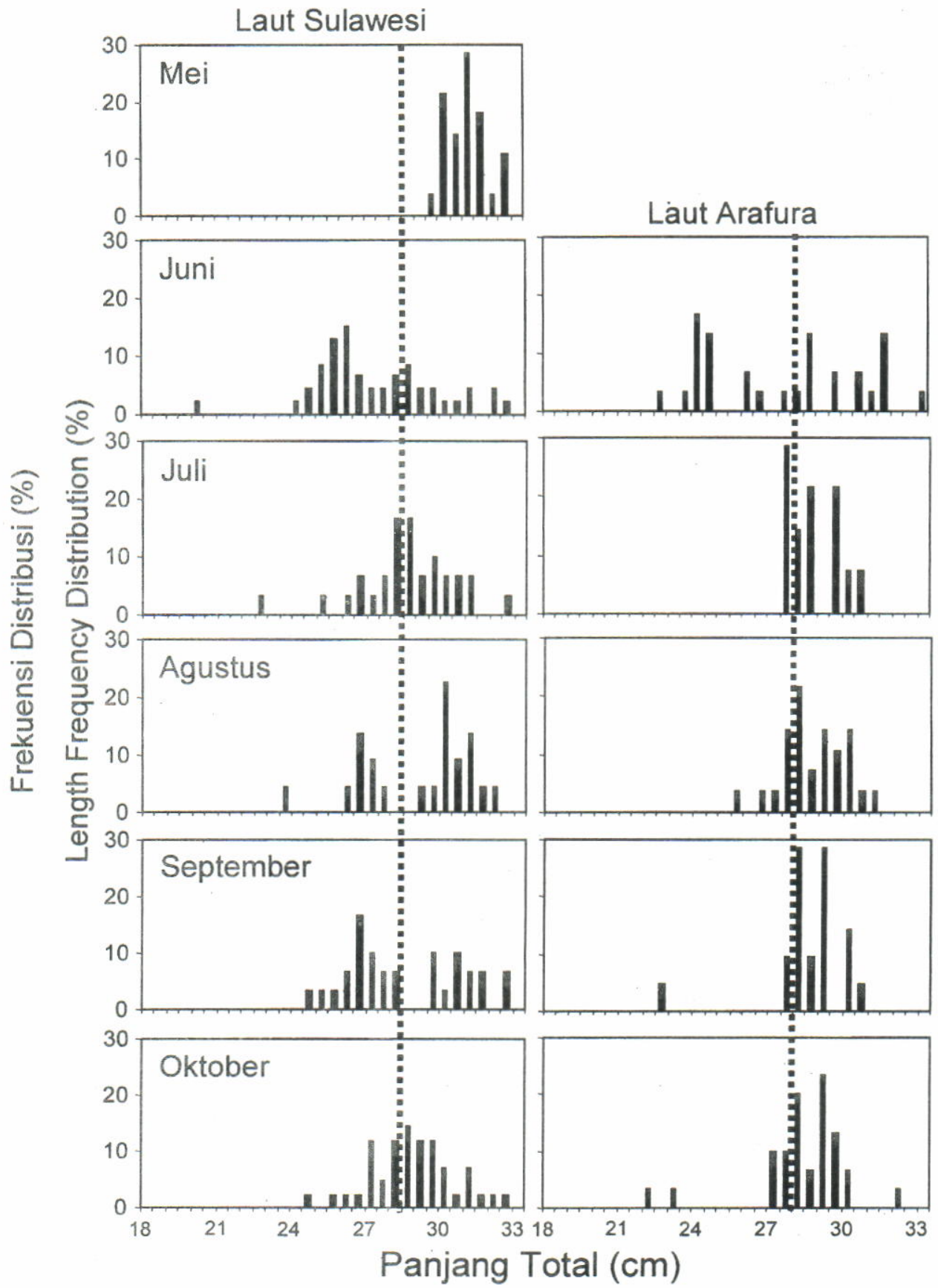

Gambar 3. Distribusi frekuensi panjang total $(\mathrm{cm})$ ikan terbang, C. spilopterus yang tertangkap dengan jaring insang di perairan Indonesia timur.

Keterangan: Garis putus-putus adalah panjang rata-rata contoh

Figure 3. Length frequency distribution $(\mathrm{cm})$ flyingfishes, $\mathrm{C}$. spilopterus caught by gill net in eastern Indonesia waters.

Remarks: Discontinued lines indicate the average length of samples

Arafura $(25,2 \pm 2,0 \mathrm{~cm})$. Selanjutnya, hasil studi tahun 1994 dari perairan Tual memperlihatkan selang panjang total C. spilopterus antara 28,5 sampai dengan $32,8 \mathrm{~cm}$ (Syam et al., 2004), dan hasil tersebut tidak berbeda dengan studi ini. Dengan demikian, ada sedikit 4 fenómena yaitu bahwa 1) terdapat perbedaan ukuran panjang antar jenis ikan terbang, sebagai contoh spilopterus memiliki ukuran panjang yang lebih dari cyanopterus; 2) seharusnya cyanopterus memiliki panjang tubuh yang lebih dari spilopterus (Fishbase; Froese \& Pauly, 2004 ), namun kenyataan data yang diperoleh dari ukuran panjang total contoh adalah sebaliknya; 3) 
sebagian besar ikan-ikan yang tertangkap merupakan ikan dewasa yang sudah pernah bereproduksi, sehingga secara teoritis ukuran mata jaring yang dipergunakan nelayan cukup memenuhi syarat ramah lingkungan; 4) kemungkinan telah terjadi adaptasi perubahan morfologi akibat tangkap lebih (overfishing) di Selat Makassar, karena ukuran ikan terbang cyanopterus tertangkap dengan ukuran yang lebih kecil. Hal ini, juga diindikasikan oleh jenis ikan terbang lain Hirundicthys oxcephalus yang tertangkap di Selat Makassar dalam 27 tahun terakhir (Ali, 2005).

\section{Faktor Kondisi}

Parameter faktor kondisi $(\mathrm{Kn})$ dari 2 jenis ikan terbang selama bulan Mei sampai dengan Oktober 2005 hampir tidak menunjukkan fluktuasi yang berarti (Gambar 4). Begitu juga dengan hasil analisis sidik ragam (ANOVA) tidak menunjukkan ada perbedaan nyata antar lokasi pada taraf uji 5\% (Tabel 3).

Indikasi dari hasil kajian faktor kondisi ini dapat mengungkapkan bahwa periode perkembangan gonad dan pemijahan ke-2 jenis ikan terbang ini cenderung sama. Hal ini, dapat terjadi karena ke-2 jenis ikan terbang ini menerima efek faktor lingkungan, seperti perubahan suhu, salinitas, arus, dan angin terhadap aspek kehidupan (termasuk reproduksi) yang juga sama. Di samping itu, fluktuasi nilai kn yang hampir tidak nampak juga memberikan makna bahwa tidak semua ikan pada ke-2 kelompok ikan terbang ini mengalami proses pematangan gonad dan memijah pada waktu yang sama. Ini berarti bahwa sebagian ikan dalam kelompok ikan terbang memijah dań sebagian lagi memasuki tahapan matang gonad, dan berulang seterusnya selama periode pemijahan yang lansung antara bulan Mei sampai dengan Oktober (Hutomo et al., 1985), sedangkan puncak pemijahan bulan Juni sampai dengan Juli (Ali, 2005).

Tabel 3. Hasil analisis varians (ANOVA) dari faktor kondisi (kn) ikan terbang C. cyanopterus dản spilopterus dari 3 lokasi, dengan menggunakan beberapa kombinasi

Table 3. ANOVA results of condition factor $(\mathrm{kn})$ of fyingfishes, C. cyanopterus and C. spilopterus collected at 3 sites, with some combinations

\begin{tabular}{|c|c|c|c|c|c|}
\hline $\begin{array}{l}\text { Sumber } \\
\text { Source }\end{array}$ & $\begin{array}{l}\text { JK } \\
\text { SS }\end{array}$ & $\begin{array}{l}\text { DB } \\
D F\end{array}$ & $\begin{array}{l}\text { KT } \\
M S\end{array}$ & $\begin{array}{c}\text { F-hitung } \\
\text { F-value }\end{array}$ & $\begin{array}{l}\text { Nilai P } \\
\text { P-value }\end{array}$ \\
\hline \multicolumn{6}{|c|}{ C. cyanopterus, 3 lokasi (Selat Makassar, Laut Sulawesi, dan Laut Arafura) } \\
\hline $\begin{array}{l}\text { Lokasi } \\
\text { Sites }\end{array}$ & 0,0097 & 2 & 0,0049 & 2,12 & $0,27 \mathrm{NS}$ \\
\hline $\begin{array}{l}\text { Residu } \\
\text { Residual }\end{array}$ & 0,0068 & 3 & 0,0023 & & \\
\hline Total & 0.0165 & 5 & & & \\
\hline \multicolumn{6}{|c|}{ C. cyanopterus, 2 lokasi (Selat Makassar dan Laut Sulawesi) } \\
\hline $\begin{array}{l}\text { Lokasi } \\
\text { Sites }\end{array}$ & 0,0011 & 1 & 0,0011 & 1,14 & $0,34 \mathrm{NS}$ \\
\hline $\begin{array}{l}\text { Residu } \\
\text { Residual }\end{array}$ & 0,0037 & 4 & 0,0009 & & \\
\hline Total & 0.0048 & 5 & & & \\
\hline \multicolumn{6}{|c|}{ C. spilopterus, 2 lokasi (Laut Sulawesi \& Laut Arafura) } \\
\hline $\begin{array}{l}\text { Lokasi } \\
\text { Sites }\end{array}$ & 0,0000 & 1 & 0,0000 & 0,00 & $1,00 \mathrm{NS}$ \\
\hline $\begin{array}{l}\text { Residu } \\
\text { Residual }\end{array}$ & 0,0276 & 8 & 0,0035 & & \\
\hline Total & 0,0276 & 9 & & & \\
\hline
\end{tabular}




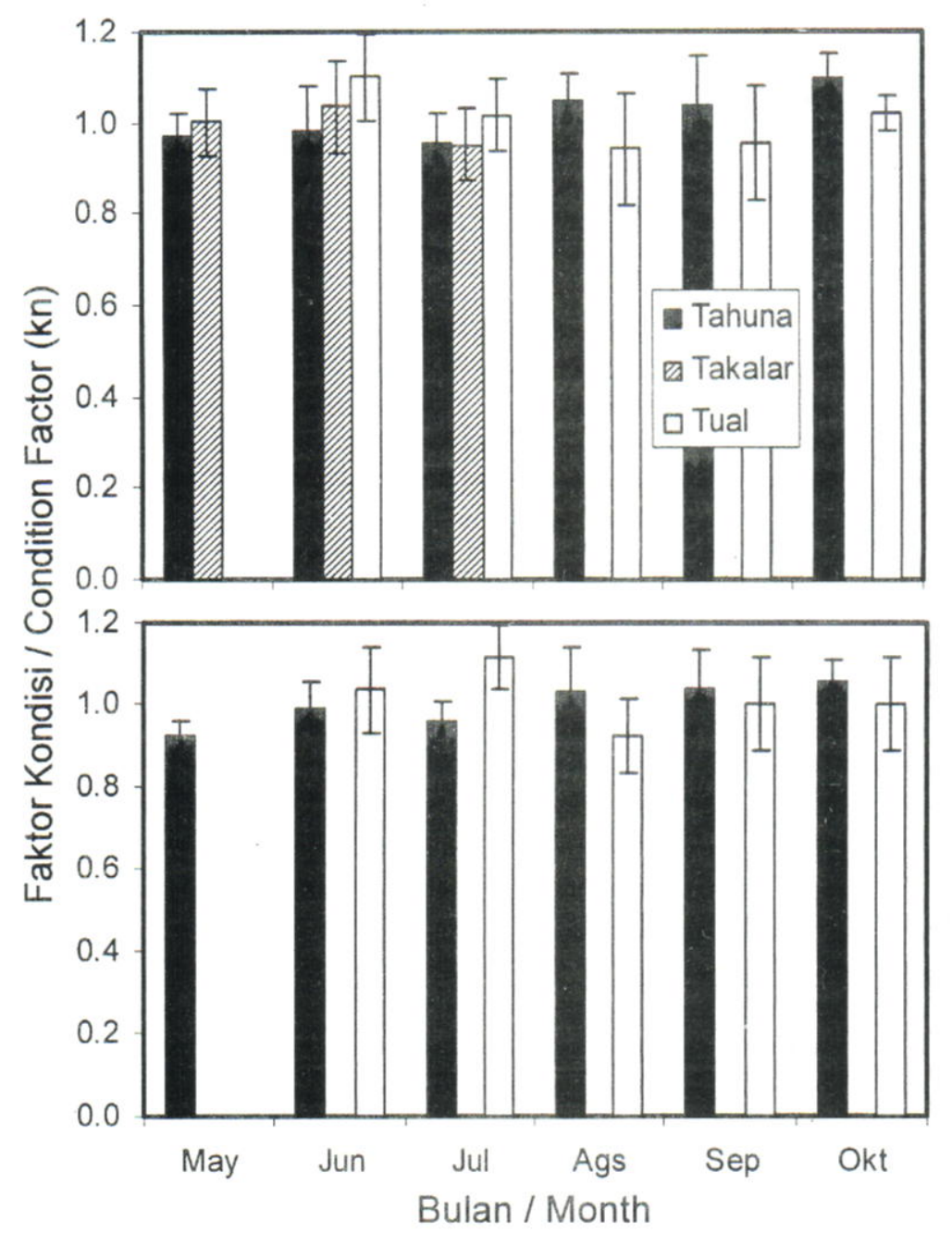

Gambar 4. Rata-rata faktor kondisi per bulan dari ikan terbang (a) C. cyanopterus dan (b) C. spilopterus yang tertangkap di Selat Makassar (didaratkan di Takalar), Laut Sulawesi (Tahuna), dan Laut Arafura (Tual), bulan Mei sampai dengan Oktober 2005.

Figure 4. Monthly average of condition factor of flyingfishes (a) C. cyanopterus and (b) C. spilopterus caught in Makassar Strait (landed in Takalar), Sulawesi Sea (Tahuna), and Arafura Sea (Tual), May to October 2005.

\section{KESIMPULAN}

1. Penggunaan jaring insang untuk penangkapan ikan terbang perlu diwaspadai untuk beberapa jenis ikan terbang, seperti jenis $C$. cyanopterus, walaupun kebanyakan ikan-ikan yang tertangkap sudah dalam kondisi dewasa.

2. Faktor kondisi jenis ikan terbang, C. cyanopterus dan C. spilopterus tidak menunjukkan perbedaan yang nyata selama periode pemijahan bulan Mei sampai dengan Oktober, mengindikasikan bahwa ke-2 jenis ikan ini mengalami proses perkembangan gonad yang sama.
3. Perikanan ikan terbang di Selat Makassar cenderung mengalami tekanan akibat eksploitasi yang berlebihan, sedangkan di Laut Sulawesi dan Laut Arafura, hal ini belum nampak.

\section{DAFTAR PUSTAKA}

Ali, S. A. 2005. Kondisi sediaan dan keragaman populasi ikan terbang, Hirundichthys oxycephalus (Bleeker, 1852) di Laut Flores dan Selat Makassar. Disertasi. Pascasarjana Universitas Hasanuddin Makassar. 
Bataragoa, N. E. 1998. Aspek reproduksi ikan terbang Cypselurus sp. (Exocoetidae) di Teluk Manado. Fakultas Perikanan dan IImu Kelautan Universitas Sam Ratulangi. Manado. 10 hal.

Cone, R. S. 1989. The need to reconsider the use of condition indices in fishery science. Transaction of American Fishery Society. 118: 510-514.

Dwiponggo, A., T. Sujastani, \& S. Nurhakim. 1983 Pengkajian potensi dan tingkat pengusahaan perikanan torani di perairan Sulawesi bagian Selatan. Laporan Penelitian Perikanan Laut. 25: 1-12.

Froese, R. \& D. Pauly (eds). 2004. Fish base 2004: Concept, design, and data source. ICLARM. Los Banos. Laguna. Phillipnes. 344 pp.

Hutomo, M., Burhanuddin, \& S. Martosuwejo. 1985 Sumber daya ikan terbang. LON-Lembaga IImu Pengetahuan Indonesia. Jakarta. 74 hal.

Kimura, S. \& K. Matsuura. 2003. Fishes of Bitung, Northern tip of Sulawesi, Indonesia. Ocean Research Institute. University of Tokyo. Tokyo. iv +244p.
Nessa, M. N., H. Sugondo, J. Andarias, \& A. Rantetondok. 1977. Studi pendahuluan terhadap perikanan ikan terbang di Selat Makassar. Majalah Universitas Hasanuddin VIIIXVIII (13): 643-669 (Edisi khusus Pola IImiah Pokok).

Parin, N. V. 1999. FAO species identification guide for fishery purposes the living marine resources of the Western Central Pacific. Vol.4 Bony Fishes Part 2 (Mugilidae to Carangidae). Food and Agriculture Organization of United Nations. Rome. 1999. pp 2162-2179.

Syam, A. R., T. Zubaidi, \& I. G. Edrus. 2004. Aspek reproduksi ikan terbang Cypselurus oligolepis dan C. spilopterus di perairan Tual, Maluku Tenggara. Jurnal Penelitian Perikanan Indonesia Edisi Sumber Daya dan Penangkapan. Vol.10. No.4: 87-95.

Syahailatua, A. 2005. Perikanan ikan terbang dan prospek pengembangannya di Indonesia; Fokus Selat Makassar, Laut Flores, dan Laut Sulawesi. Laporan Akhir Penelitian. Program Penelitian dan Pengembangan IImu Pengetahuan dan Teknologi Riset Kompetitif Lembaga Ilmu Pengetahuan Indonesia. 68 hal. 